\title{
Breast density predicts endocrine treatment outcome in the adjuvant setting
}

\author{
Jack Cuzick* \\ See related research article by Kim et al., http://breast-cancer-research.com/content/14/4/R102.
}

\begin{abstract}
In their report, Kim and colleagues study the ability of changes in mammographic density over a period of 12 to 18 months to predict subsequent recurrence in 1,065 Korean women with oestrogen receptor-positive breast cancer. Based on 80 recurrences, a clear gradient for lower recurrence rates was seen among women with larger density reductions - with recurrence rates being more than twofold higher in women with no reduction compared with those presenting a reduction $\geq 10 \%$. This extends previous work on predicting the effectiveness of tamoxifen in individual women from the preventive setting to the adjuvant setting, and also includes women treated with aromatase inhibitors, where a slightly larger effect was seen.
\end{abstract}

The report by Kim and colleagues makes an important contribution to tailoring endocrine therapy in oestrogen receptor-positive breast cancer to women most likely to benefit from it [1]. Oestrogen receptor-positive breast cancer is unique among common solid tumours in that it has a very long natural history, and it is not possible to accurately identify women who can safely be considered cured. As a result endocrine therapy is required for at least 5 years, and often longer for high-risk patients. Yet late recurrences are still common, being about $2.5 \%$ per year for 20 years with tamoxifen treatment [2] and about $2 \%$ per year with aromatase inhibitors for the 10 years for which follow-up data are currently available [3].

Aside from levels of oestrogen and progesterone receptors measured in the primary tumour, little information is available to predict response to treatment. Newer studies focusing on changes in Ki-67 and other cell cycle proteins measured before and after presurgical treatment

*Correspondence: j.cuzick@qmul.ac.uk

Centre for Cancer Prevention, Wolfson Institute of Preventive Medicine, Queen Mary University of London, London EC1M 6BQ, UK may in the future help to determine which patients are responding to a given treatment [4], but current practise is to give at least 5 years of endocrine treatment to all patients and hope for the best. Early suggestions that 2D6 polymorphisms, which are involved in the metabolism of tamoxifen, might help to predict which patients would respond best to this treatment have not been confirmed in more recent large studies $[5,6]$.

Breast density is a well-established risk factor for breast cancer in Caucasian women [7], and also in oriental women although their average density is higher [8]. Breast density responds to hormonal manipulations, being increased with hormone replacement therapy [9] and importantly reduced with the use of tamoxifen [10]. The possibility that changes in density might predict drug effectiveness was hypothesised some time ago [10]. This prediction was subsequently shown to be the case in the preventive setting, where tamoxifen reduced the incidence of breast cancer in high-risk women by about twothirds when density was reduced by $10 \%$ or more after 12 to 18 months of treatment but had no effect when reductions were smaller or nonexistent [11]. The possibility that the same predictive value of density might also be true in the adjuvant setting and also for aromatase inhibitors was raised in [11], and the current study is the first to report such an effect.

In their report, Kim and colleagues studied 1,065 Korean women with oestrogen receptor-positive breast cancer, of which 127 (12\%) had ductal carcinoma in situ [1]. All patients received endocrine therapy (tamoxifen or an aromatase inhibitor) for a mean duration of 5.1 years. Density was assessed in the cranio-caudal view of the contralateral breast at baseline and at a mean of 13.1 months after the start of therapy - blinded to treatment allocation and outcome - using the Cumulus software [12]. Sixty per cent of women had baseline density in the 25 to $50 \%$ range. Based on 80 recurrences overall, a clear gradient for lower recurrence rates in women with large reductions was seen - recurrence rates being more than twofold higher in women with no reduction compared with those presenting a reduction $\geq 10 \%$. About onequarter of women had changes in each of the four 
categories of reduction: $>10 \%, 5$ to $10 \%, 0$ to $5 \%$, or an increase.

Greater density reductions were seen in women receiving tamoxifen (6.5\% mean reduction) than in those receiving an aromatase inhibitor (3.1\% mean reduction), but this appears to be due to their younger age and consequently their higher density at entry. Although tamoxifen was associated with greater changes in density, curiously the predictive value of density appeared to be greater with aromatase inhibitors and in postmenopausal women. The reasons for this increased density are unclear and need confirmation in further studies. Mechanisms underlying these findings are also needed, and if found could help to identify those women most likely to respond to a specific treatment before it is started, as opposed to the need to wait for the approximately 12 to 18 months after treatment has commenced to identify density changes in mammograms.

This study is the first to show that change in density predicts recurrences in the adjuvant setting, and raises the possibility of adjusting treatment in individual women according to their initial response to treatment in terms of density changes. This is an important step toward personalising treatment for this disease. Further work in Caucasian populations - more closely controlled for age and specific treatment, and integrating other factors such as levels of oestrogen and progesterone receptors, and baseline Ki-67 levels (and possibly, when presurgical endocrine treatment is used, evaluating changes in Ki-67 positivity in the tumour) - offers the prospect of more accurately choosing a specific treatment from which an individual woman is most likely to benefit.

\section{Competing interests}

$\mathrm{JC}$ is a former advisory board member for AstraZeneca, and receives ongoing research support to his institution for the IBIS2 prevention trial from AstraZeneca.

Published: 13 August 2012

\section{References}

1. Kim J, Han W, Moon H-G, Ahn SK, Shin H-C, You J-M, Han S-W, Im S-A, Kim T-Y, Koo HR, Chang JM, Cho N, Moon WK, Noh DY: Breast density change as a predictive surrogate for response to adjuvant endocrine therapy in hormone receptor positive breast cancer. Breast Cancer Res 2012, 14:R102.

2. Early Breast Cancer Trialists' Collaborative Group: Relevance of breast cancer hormone receptors and other factors to the efficacy of adjuvant tamoxifen: patient-level meta-analysis of randomised trials. Lancet 2011, 378:771-784.

3. Cuzick J, Sestak I, Baum M, Buzdar A, Howell A, Dowsett M, Forbes JF; ATAC/LATTE Investigators: Effect of anastrozole and tamoxifen as adjuvant treatment for early-stage breast cancer: 10-year analysis of the ATAC trial. Lancet Oncol 2010, 11:1109-1110.

4. Dowsett M, Nielsen TO, A'Hern R, Bartlett J, Coombes RC, Cuzick J, Ellis M, Henry NL, Hugh JC, Lively T, McShane L, Paik S, Penault-Llorca F, Prudkin L, Regan M, Salter J, Sotiriou C, Smith IE, Viale G, Zujewski JA, Hayes DF; International Ki-67 in Breast Cancer Working Group: Assessment of Ki67 in breast cancer: recommendations from the International Ki67 in Breast Cancer Working Group. J Natl Cancer Inst 2011, 103:1656-1664.

5. Rae JM, Drury S, Hayes DF, Stearns V, Thibert JN, Haynes BP, Salter J, Sestak I, Cuzick J, Dowsett M; ATAC Trialists: CYP2D6 and UGT2B7 genotype and risk of recurrence in tamoxifen-treated breast cancer patients. J Nat/ Cancer Inst 2012, 104:452-460.

6. Regan MM, Leyland-Jones B, Bouzyk M, Pagani O, Tang W, Kammler R, Dell'orto P, Biasi MO, Thürlimann B, Lyng MB, Ditzel HJ, Neven P, Debled M, Maibach R, Price KN, Gelber RD, Coates AS, Goldhirsch A, Rae JM, Viale G; Breast International Group 1-98 Collaborative Group: CYP2D6 genotype and tamoxifen response in postmenopausal women with endocrineresponsive breast cancer: the Breast International Group 1-98 Trial. J Natl Cancer Inst 2012, 104:441-451.

7. Boyd NF, Martin LJ, Bronskill M, Yaffe MJ, Duric N, Minkin S: Breast tissue composition and susceptibility to breast cancer. J Nat / Cancer Inst 2010, 102:1224-1237.

8. Wong CS, Lim GH, Gao F, Jakes RW, Offman J, Chia KS, Duffy SW: Mammographic density and its interaction with other breast cancer risk factors in an Asian population. Br J Cancer 2011, 104:871-874.

9. Greendale GA, Reboussin BA, Slone S, Wasilauskas C, Pike MC, Ursin G: Postmenopausal hormone therapy and change in mammographic density. J Natl Cancer Inst 2003, 95:30-37.

10. Cuzick J, Warwick J, Pinney E, Warren RM, Duffy SW: Tamoxifen and breast density in women at increased risk of breast cancer. J Natl Cancer Inst 2004, 96:621-628.

11. Cuzick J, Warwick J, Pinney E, Duffy SW, Cawthorn S, Howell A, Forbes JF, Warren RM: Tamoxifen-induced reduction in mammographic density and breast cancer risk reduction: a nested case-control study. J Natl Cancer Inst 2011, 103:744-752

12. Byng JW, Boyd NF, Fishell E, Jong RA, Yaffe MJ: The quantitative analysis of mammographic densities. Phys Med Biol 1994, 39:1629-1638.

doi:10.1186/bcr3235

Cite this article as: Cuzick J: Breast density predicts endocrine treatment outcome in the adjuvant setting. Breast Cancer Research 2012, 14:109. 